\title{
Photocatalytic trifluoromethoxylation of arenes and heteroarenes in continuous-flow
}

\author{
Alexander V. Nyuchev ${ }^{1}$, Ting Wan ${ }^{1}$, Borja Cendón ${ }^{1,2}$, Carlo Sambiagio ${ }^{1}$, \\ Job J. C. Struijs ${ }^{1}$, Michelle Ho ${ }^{1}$, Moisés Gulías ${ }^{2}$, Ying Wang ${ }^{3}$ and Timothy Noël ${ }^{* 1}$
}

\section{Full Research Paper}

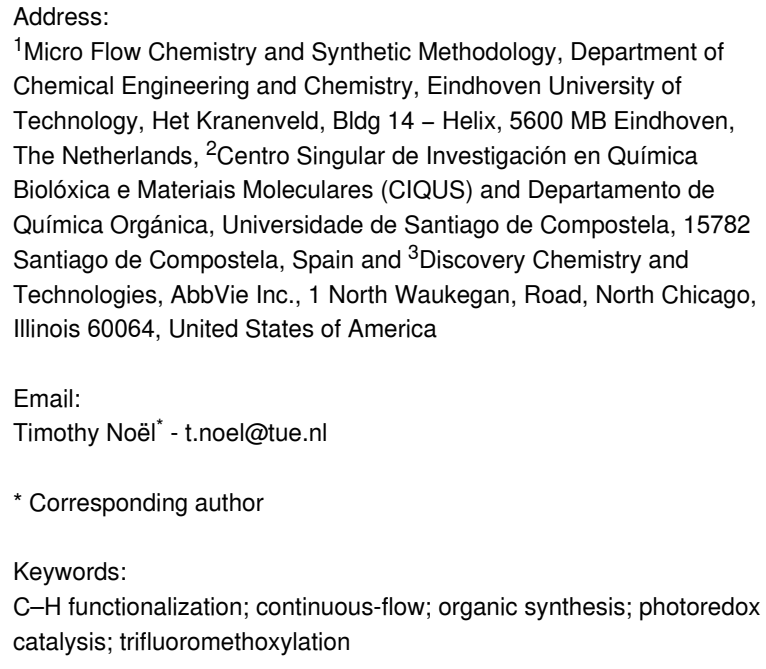

${ }^{1}$ Micro Flow Chemistry and Synthetic Methodology, Department of Chemical Engineering and Chemistry, Eindhoven University of Technology, Het Kranenveld, Bldg 14 - Helix, 5600 MB Eindhoven, The Netherlands, ${ }^{2}$ Centro Singular de Investigación en Química Biolóxica e Materiais Moleculares (CIQUS) and Departamento de Química Orgánica, Universidade de Santiago de Compostela, 15782 Santiago de Compostela, Spain and ${ }^{3}$ Discovery Chemistry and Technologies, AbbVie Inc., 1 North Waukegan, Road, North Chicago, Illinois 60064, United States of America

Email:

Timothy Noël* - t.noel@tue.nl

* Corresponding author

Keywords:

C-H functionalization; continuous-flow; organic synthesis; photoredox catalysis; trifluoromethoxylation

Beilstein J. Org. Chem. 2020, 16, 1305-1312. doi:10.3762/bjoc.16.111

Received: 12 April 2020

Accepted: 24 May 2020

Published: 15 June 2020

This article is part of the thematic issue "Advances in photoredox catalysis".

Associate Editor: B. Nay

(C) 2020 Nyuchev et al.; licensee Beilstein-Institut. License and terms: see end of document.

\section{Abstract}

The first example of photocatalytic trifluoromethoxylation of arenes and heteroarenes under continuous-flow conditions is described. Application of continuous-flow microreactor technology allowed to reduce the residence time up to 16 times in comparison to the batch procedure, while achieving similar or higher yields. In addition, the use of inorganic bases was demonstrated to increase the reaction yield under batch conditions.

\section{Introduction}

The number of fluorine-containing compounds and their influence in medicine and agrochemistry are increasing every year $[1,2]$. The introduction in a drug (or a bioactive compound in general) of single fluorine atoms, or multiple fluorine-containing substituents, such as $-\mathrm{CF}_{3},-\mathrm{SCF}_{3},-\mathrm{CF}_{2} \mathrm{H} /-\mathrm{CF}_{2^{-}}$, has a range of effects on the pharmacokinetics and pharmacodynamics of the molecule [3]. Among other fluorine-based substituents, the trifluoromethoxy group $\left(-\mathrm{OCF}_{3}\right)$ has until recently remained less explored and understood [4]. Nonetheless, it possesses unique properties, for example, a high electronegativity $(x=3.7)$, and a high lipophilicity (Hansch-Leo parameter $\pi=1.04$, intermediate between the $-\mathrm{CF}_{3}$ and the $-\mathrm{SCF}_{3}$ values, respectively, 0.88 and 1.44) [4]. From a pharmaceutical perspective, the former property provides stability of the drug under physiological conditions, and the latter ensures better solubility and transport across the physiological lipophilic environment (e.g., dissolution in lymph and cell membrane penetration) [5]. In trifluoromethoxylated aryls, the $-\mathrm{OCF}_{3}$ group 
assumes a peculiar orthogonal conformation relative to the aromatic ring, partially due to the hyperconjugation of an oxygen lone pair with an antibonding $\mathrm{C}-\mathrm{F}$ orbital, and partially to the steric hindrance of the $-\mathrm{CF}_{3}$ group [6,7]. These interac- tions result in a relative conformational flexibility, where the $-\mathrm{OCF}_{3}$ group can rotate between the two sides of the aromatic ring (Scheme 1A). This property might be responsible for stronger binding affinities of trifluoromethoxylated compounds

A) The $-\mathrm{OCF}_{3}$ group

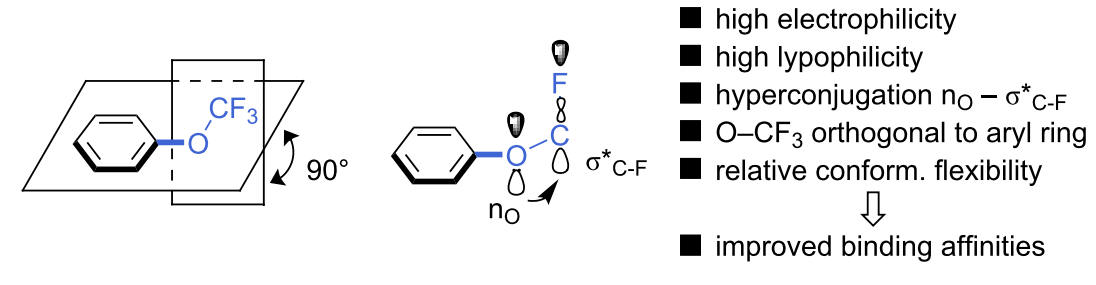

B) Synthetic approaches

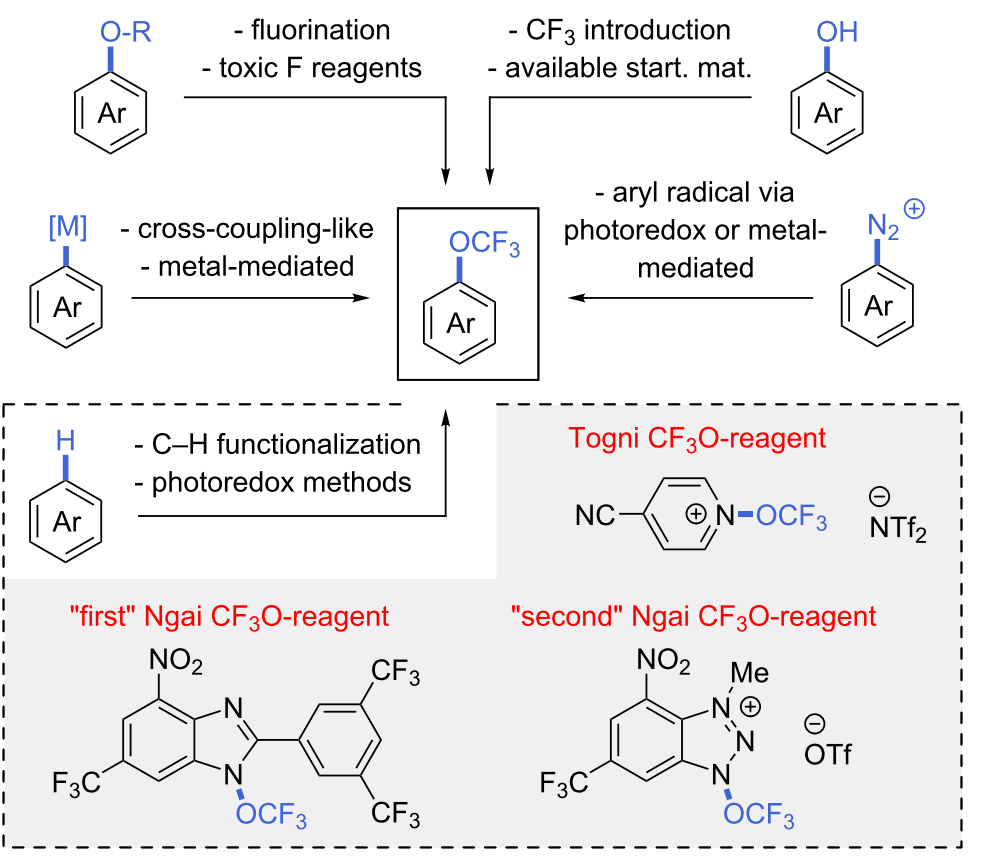

C) Mechanistic cycle - "second" Ngai $\mathrm{CF}_{3} \mathrm{O}$-reagent

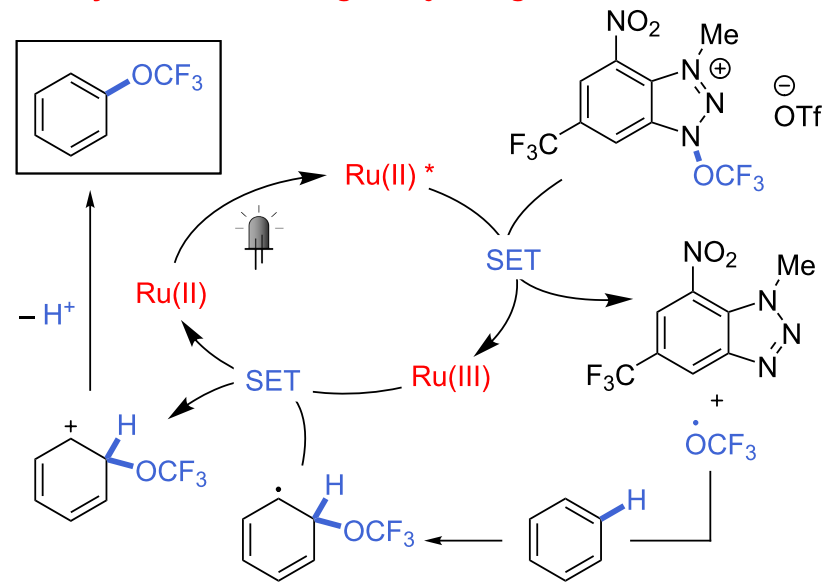

Scheme 1: A) Properties and B) synthesis of $\mathrm{CF}_{3} \mathrm{O}$-bearing arenes; C) trifluoromethoxylation using the "second" Ngai reagent. 
with the active sites in enzymes, proteins, or other biomolecules $[8,9]$.

Several procedures for the synthesis of trifluoromethyl aryl ethers were reported from the mid-1900s, mostly based on the transformation of pre-functionalized aryls, such as trichloromethyl ethers, fluoroformates, or carbonochloridothionate derivatives. These procedures typically required harsh conditions and the use of aggressive and toxic chemicals like $\mathrm{BF}_{3}, \mathrm{HF}, \mathrm{MoF}_{6}, \mathrm{SF}_{4}$, and $\mathrm{SbF}_{3}$ [10]. Alternative approaches were recently reported $[8,9,11]$, for example the trifluoromethylation of hydroxyaryls [12-14], and the direct introduction of the $-\mathrm{OCF}_{3}$ moiety into an organometallic species [15], a diazo compound [16,17], or an unfunctionalized $\mathrm{C}-\mathrm{H}$ bond (Scheme 1B). The latter method is particularly interesting, partially due to the general interest of the community into $\mathrm{C}-\mathrm{H}$ functionalization methodologies $[18,19]$, and partially thanks to the synthetic possibilities enabled by photoredox catalysis, a field widely explored in recent years [20-22]. In 2018, Ngai [23,24] and Togni [25] reported simple photoredox protocols for the radical trifluoromethoxylation of unfunctionalized (hetero)arenes by using specifically designed $\mathrm{CF}_{3} \mathrm{O}$ radical-releasing agents (Scheme 1B).

Table 1: Reaction optimization under flow conditions

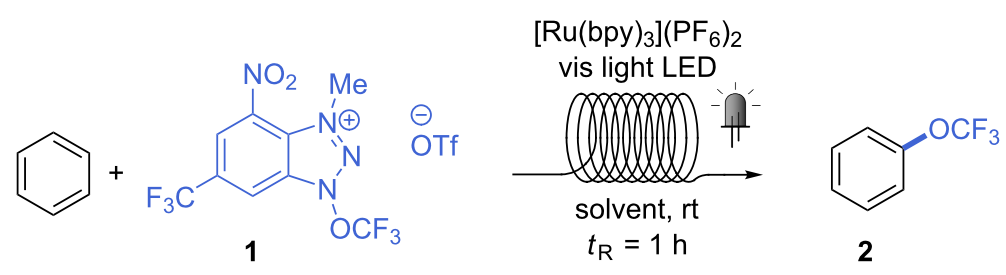

\begin{tabular}{|c|c|c|c|c|c|}
\hline Entry & Equiv of substrate & Solvent, conc. of $1(\mathrm{M})$ & Light source & Cat. (\%) & Yield $(\%)^{\mathrm{a}}$ \\
\hline 1 & 25 & $\mathrm{CH}_{3} \mathrm{CN} / \mathrm{CH}_{2} \mathrm{Cl}, 0.04$ & $465 \mathrm{~nm}, 18 \mathrm{~W}$ & 1 & 40 \\
\hline 2 & 25 & $\mathrm{CH}_{3} \mathrm{CN} / \mathrm{CH}_{2} \mathrm{Cl}, 0.04$ & $400 \mathrm{~nm}, 10 \mathrm{~W}$ & 1 & 52 \\
\hline 3 & 25 & $\mathrm{CH}_{3} \mathrm{CN}, 0.04$ & $400 \mathrm{~nm}, 10 \mathrm{~W}$ & 1 & 53 \\
\hline 4 & 25 & $\mathrm{CH}_{3} \mathrm{CN}, 0.04$ & $400 \mathrm{~nm}, 10 \mathrm{~W}$ & 2 & 68 \\
\hline 5 & 25 & $\mathrm{CH}_{3} \mathrm{CN}, 0.08$ & $400 \mathrm{~nm}, 10 \mathrm{~W}$ & 1 & 65 \\
\hline 6 & 25 & $\mathrm{CH}_{3} \mathrm{CN}, 0.08$ & $400 \mathrm{~nm}, 10 \mathrm{~W}$ & 2 & 64 \\
\hline 7 & 10 & $\mathrm{CH}_{3} \mathrm{CN}, 0.08$ & $400 \mathrm{~nm}, 10 \mathrm{~W}$ & 1 & 57 \\
\hline 8 & 10 & $\mathrm{CH}_{3} \mathrm{CN}, 0.08$ & $400 \mathrm{~nm}, 10 \mathrm{~W}$ & 1 & $63^{b}$ \\
\hline 9 & 10 & $\mathrm{CH}_{3} \mathrm{CN}, 0.2$ & $400 \mathrm{~nm}, 10 \mathrm{~W}$ & 1 & 61 \\
\hline 10 & 10 & $\mathrm{CH}_{3} \mathrm{CN}, 0.08$ & $400 \mathrm{~nm}, 10 \mathrm{~W}$ & 1 & $73^{c}$ \\
\hline \multicolumn{6}{|c|}{ control experiments } \\
\hline 11 & 25 & $\mathrm{CH}_{3} \mathrm{CN}, 0.04$ & $465 \mathrm{~nm}, 18 \mathrm{~W}$ & 1 & $10^{d}$ \\
\hline 12 & 25 & $\mathrm{CH}_{3} \mathrm{CN}, 0.04$ & $400 \mathrm{~nm}, 10 \mathrm{~W}$ & 0 & 17 \\
\hline 13 & 25 & $\mathrm{CH}_{3} \mathrm{CN}, 0.04$ & $465 \mathrm{~nm}, 18 \mathrm{~W}$ & 0 & 0 \\
\hline
\end{tabular}

${ }^{\text {a }}{ }^{19}$ F NMR yields are reported; ${ }^{b}$ Degassed solvent; ${ }^{c}$ Freshly prepared; $d$ [Ir(dtbbpy)(ppy) $\left.{ }_{2}\right] P F_{6}$ as catalyst.

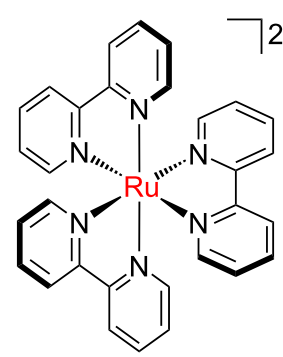

$\left[\mathrm{Ru}(\mathrm{bpy})_{3}\right]\left(\mathrm{PF}_{6}\right)_{2}$<smiles></smiles>

$\left[\operatorname{lr}(\right.$ dtbbpy $\left.)(\text { ppy })_{2}\right] \mathrm{PF}_{6}$ 
Following our long-standing interest in the development of continuous-flow approaches for C-H functionalization $[18,26]$ and photochemical methodologies [27-31], herein we report the first application of flow methods for the direct trifluoromethoxylation of arenes and heteroarenes.

\section{Results and Discussion}

Among the three reagents shown in Scheme 1B, we decided to use the "second" Ngai reagent $(\mathbf{1}$, Scheme $1 \mathrm{C})$ for our investigation, as less side-products (derived from alternative radical formation from the other two reagents $[23,25]$ ) and tolerance towards water and air gives this reagent a certain advantage over the others [24]. To transfer the batch procedure into continuous-flow conditions, the concentration of $\mathbf{1}$ was initially decreased from the original $0.2 \mathrm{M}$ to $0.04 \mathrm{M}$, and the amount of substrate increased from 10 to 25 equivalents, while the same catalyst $\left(\left[\mathrm{Ru}(\mathrm{bpy})_{3}\right]\left(\mathrm{PF}_{6}\right)_{2}\right)$ and reaction medium $\left(\mathrm{CH}_{3} \mathrm{CN} / \mathrm{CH}_{2} \mathrm{Cl}_{2}\right.$ 1:1) were used. Upon irradiation with blue light (465 nm, $18 \mathrm{~W}$ LED), the desired trifluoromethoxybenzene (2) was obtained in $40 \%$ yield after a residence time of $1 \mathrm{~h}$ (Table 1, entry 1). A $400 \mathrm{~nm}$ LED light led to a higher yield (52\%, Table 1, entry 2 ), thus this light source was used for further investigations. As $\mathrm{CH}_{2} \mathrm{Cl}_{2}$ is not a recommended solvent, especially for industrial and pharmaceutical applications [32], we tested the reaction in pure acetonitrile. As the same yield was obtained (Table 1, entry 3 ), this solvent was chosen as reaction medium for the following experiments. Either doubling the amount of catalyst or reducing the concentration resulted in considerably higher reaction yields (68 and $65 \%$, Table 1 , entries 4 and 5). Increased catalyst loading at $0.08 \mathrm{M}$ produced no improvement (Table 1, entry 6). We next tested the reaction using a lower excess of substrate (10 equiv), obtaining product 2 in 57\% yield (Table 1, entry 7). Little improvement was seen upon degassing the reaction mixture prior to the reaction (three freeze-pump-thaw cycles, $63 \%$, Table 1, entry 8). Performing the reaction at $0.2 \mathrm{M}$ concentration gave $61 \%$ yield (Table 1 , entry 9). Last, we were particularly pleased to see that a sensible increase in yield could be obtained by using a freshly prepared reagent $\mathbf{1}$ in the reaction (the activity of reagent $\mathbf{1}$ persists at a primary level during near two weeks when stored in the dark at $-20{ }^{\circ} \mathrm{C}$ ). A yield of $73 \%$ could be achieved at $0.08 \mathrm{M}$, without the tedious degassing procedure (Table 1, entry $10)$.

Finally, a few control experiments were performed (Table 1, entries 11-13). A more expensive Ir photocatalyst was tested under blue light irradiation, but a poor $10 \%$ yield was obtained. Experiments in the absence of photocatalyst under violet or blue light gave respectively $17 \%$ and $0 \%$ yield. The little product obtained with $400 \mathrm{~nm}$ light can be explained by the photodecomposition of $\mathbf{1}$, which generates small amounts of $\mathrm{CF}_{3} \mathrm{O}$ radical (this has been shown for the "first" Ngai reagent [23]).

Under the conditions shown in Table 1, entry 10 , we then set to figure out the optimal residence time $\left(t_{\mathrm{R}}\right)$ for the reaction (Scheme 2). Yields of around $70 \%$ were observed for the trifluoromethoxylation of benzene even at 20 minutes residence time, which demonstrates the effectiveness of the flow process (a yield of $63 \%$ was obtained in batch over $16 \mathrm{~h}$ [24]). However, unreacted 1 was observed at this residence time, and full conversion could be obtained only after $1 \mathrm{~h}$. Moreover, a resi-

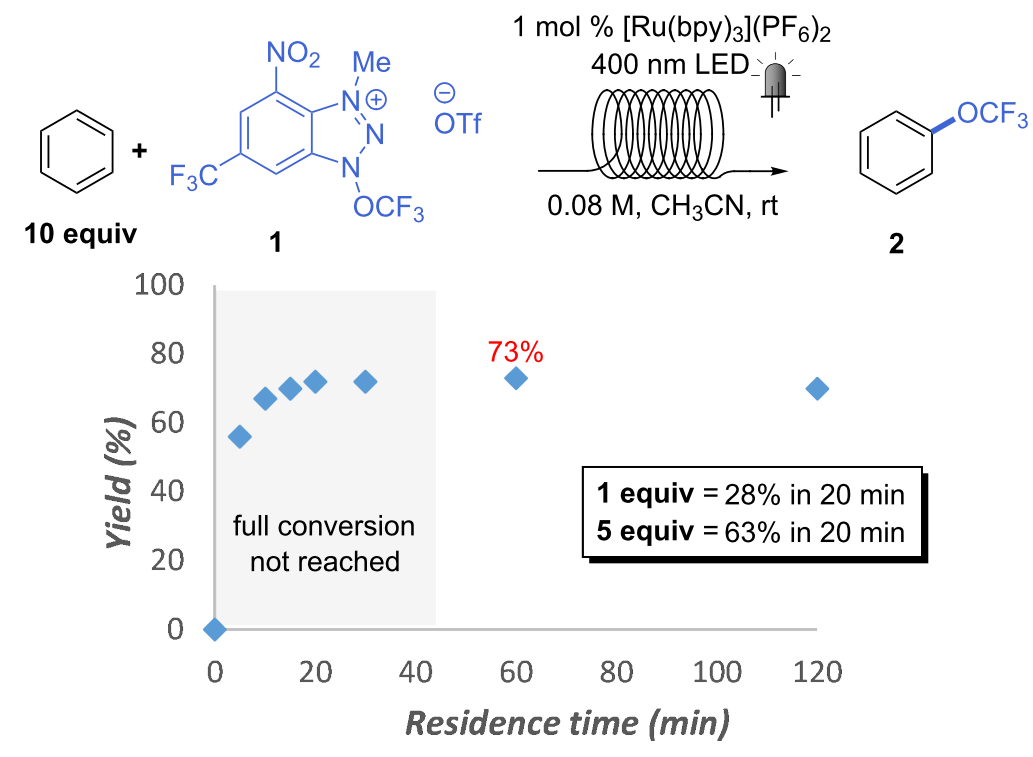

Scheme 2: Optimization of residence time. ${ }^{19} \mathrm{~F}$ NMR yields are reported. 


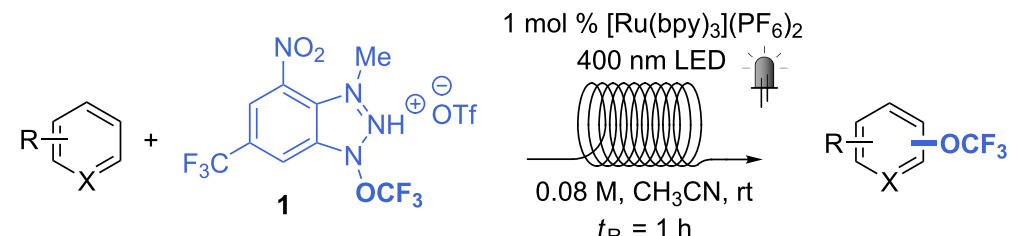

$t_{\mathrm{R}}=1 \mathrm{~h}$

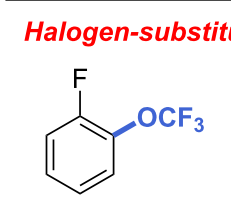

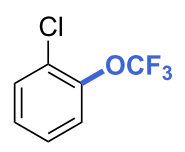<smiles>FC(F)(F)Oc1ccccc1Br</smiles><smiles>FC(F)(F)Oc1ccc(I)cc1</smiles>

3, $53 \%$ (o:m: $: p=$ $2.2: 1: 1.8)$

\section{4, $66 \%$}

5, $59 \%$

$(o: m: p=3: 1: 2)$

6, $23 \%$

$(o: m: p=1: 1: 1.2)$<smiles>CC(F)(F)Oc1c(Cl)cc(Cl)cc1Br</smiles>

$8,60 \%$ b<smiles>O=[N+]([O-])c1c(Cl)ccc(OCC(F)(F)F)c1Cl</smiles>

9, $63 \%$<smiles>CCOc1cc(C(F)(F)F)ccc1Cl</smiles>

$10,50 \%$<smiles>N#Cc1c(Cl)ccc(OC(F)(F)F)c1Cl</smiles>

$11,61 \%$ c<smiles>CC(=O)c1cccc(OC(F)(F)F)c1</smiles>

$$
\begin{array}{crr}
12,61 \% & 13,36 \% & 14,72 \% \\
(o: m: p=2.1: 2.2: 1) & (4.6: 1) & (o: m: p=1.3: 1
\end{array}
$$<smiles>CCOC(=O)c1ccc(C(=O)OCC)c(OCC(F)(F)F)c1</smiles>

$$
\begin{aligned}
& 15,57 \% \\
& \text { (o:m:p = 2.3:2.3:1) } \\
& \text { 16, } 29 \%
\end{aligned}
$$

\begin{tabular}{|c|c|c|c|c|}
\hline $\begin{array}{c}20,61 \% \\
(o: m: p=1.8: 2.4: 1)\end{array}$ & $\begin{array}{r}21,55 \% \\
(3.1: 1)\end{array}$ & $\begin{array}{c}22,42 \%^{c} \\
(o: m: p=1.1: 1.6: 1)\end{array}$ & $\begin{array}{r}23,49 \% \\
(1.3: 1)\end{array}$ & $\begin{array}{c}\mathbf{2 4}, 54 \% \\
(o: m: p=2.5: 1.9: 1)\end{array}$ \\
\hline
\end{tabular}<smiles>O=C(O)c1cccc(OC(F)(F)F)c1</smiles><smiles>Cc1c(F)cc(C(=O)O)c(OC(F)(F)F)c1F</smiles><smiles>NC(=O)c1cccc(OC(F)(F)F)c1</smiles><smiles>CCOc1cccc2c1C(=O)N([N+](=O)[O-])C2=O</smiles>

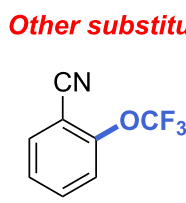

24, $54 \%$ $(o: m: p=2.5: 1.9: 1)$<smiles>N#Cc1ccc(-c2ccc(C#N)cc2OC(F)(F)F)cc1</smiles>

$25,57 \%$ d

$(1.7: 1)$<smiles>O=[N+]([O-])c1ccccc1OC(F)(F)F</smiles>

26, $41 \%$ (o:m:p = 2.4:1:1.7)<smiles>CC(C)(C)c1ccc(OC(F)(F)F)cc1</smiles><smiles>O=[N+]([O-])c1cccc(OC(F)(F)F)c1</smiles><smiles>O=S(=O)(c1ccccc1)c1cccc(OC(F)(F)F)c1</smiles>

$29,65 \%$ a (o:m:p = 1:3.5:1.2)

(o:m:p = 1:7.4:1.6)<smiles>[10BH2]c1ccc(Br)c(OC(F)(F)F)c1</smiles>

$30,26 \%$ d<smiles>CC(C)(F)Oc1ccc(Cl)nc1Cl</smiles>
(o:m:p = 1:2.6:3.6)<smiles>CCOc1c(Cl)nc(Cl)nc1Cl</smiles>

$33,65 \%$

$32,55 \%$<smiles>Cc1nc(Cl)c(OCl)c(Cl)n1</smiles><smiles>N#Cc1cc(Br)c(OC(F)(F)F)s1</smiles><smiles>O=Cc1cc(Br)c(OC(F)(F)F)s1</smiles><smiles>FC(F)(F)Oc1scc(Br)c1Br</smiles>

$31,64 \%$

$35,50 \%$
$(8.2: 1)$

$36,50 \%$

$37,53 \%$

$34,59 \%$
$(8.3: 1)$

(10.4:1) 
dence time of 20 minutes proved not sufficient for several other substrates, thus $1 \mathrm{~h}$ was chosen as the standard for the following scope. It is worth mentioning that a lower excess of substrate at 20 minutes residence time gave much lower yields of 2 (63 and $28 \%$ for 5 and 1 equiv, respectively).

With the optimized conditions in hands, we proceeded to investigate the trifluoromethoxylation of different arenes and heteroarenes in acetonitrile. Solvent mixtures and lower concentrations had to be used in some cases due to solubility issues. As can be seen in Scheme 3, trifluoromethoxylation occurs preferentially at the most electron-rich site of the arenes, although sensitivity to steric hindrance was observed. The reactions with halogenated aryls occurred smoothly, leading to products 3-11 in good yields. An exception is represented by iodobenzene, which could be methoxylated in only $23 \%$ yield (product 6 ). Similar results were obtained with carbonyl-containing com- pounds. Different aromatic ketones, aldehydes, esters, and carboxylic acids were transformed to the corresponding trifluoromethoxylated compounds (12-23) with generally good to high yields, except for 13, 16, 19 and 22 which were obtained in moderate or poor yields. Other synthetically useful substituents, including cyano, nitro, phenylsulphonyl, (pinacolato)boron, and alkyl groups could be tolerated in the reaction (24-30), leading to a yield range between 26 and $65 \%$. The trifluoromethoxylation of pyridine, pyrimidine, and thiophene derivatives also took place smoothly, giving products $\mathbf{3 1 - 3 7}$ in good yields (50-65\%).

Overall, the yields obtained for different products were similar to those reported by Ngai [24] and Togni [25] using batch protocols. In addition, in comparison with Ngai's protocol, this flow method allows for a much reduced reaction (residence) time, therefore, demonstrating the potentials of this technology

Table 2: Influence of bases on the photoredox trifluoromethoxylation in batch and flow.

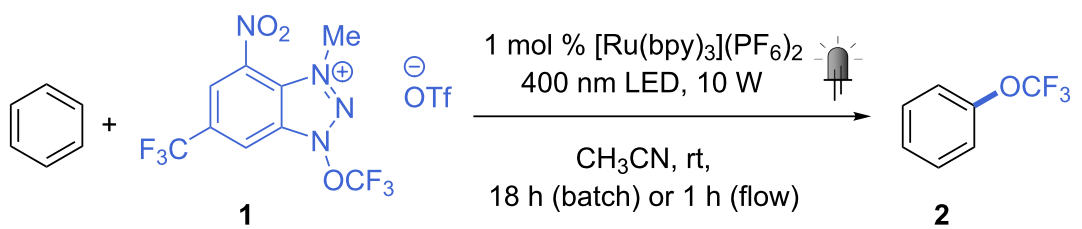

\begin{tabular}{ccccc}
\hline Entry & Equiv of substrate & Conc. of $\mathbf{1}(\mathrm{M})$ & Base & Yield (\%) \\
\hline \multicolumn{5}{c}{ organic/soluble bases } \\
\hline 1 & 10 & 0.08 & $\left(\mathrm{Bu}_{4} \mathrm{~N}\right) \mathrm{H}_{2} \mathrm{PO}_{4}, 1$ equiv & 20 \\
2 & 10 & 0.08 & $\left(\mathrm{Bu}_{4} \mathrm{~N}\right) \mathrm{H}_{2} \mathrm{PO}_{4}, 1$ equiv & 6 (flow) \\
3 & 25 & 0.04 & DIPEA, 1 equiv & 18 \\
4 & 25 & 0.04 & DBU, 1 equiv & 14 (flow) \\
5 & 25 & 0.04 & $($ Bun & (flow)
\end{tabular}

\begin{tabular}{ccccc}
\hline \multicolumn{5}{c}{ inorganic bases } \\
\hline 6 & 25 & 0.04 & $\mathrm{~K}_{2} \mathrm{CO}_{3}, 1$ equiv & 54 \\
7 & 25 & 0.04 & $\mathrm{~K}_{2} \mathrm{HPO}_{4}, 1$ equiv & 86 \\
8 & 25 & $\mathrm{~K}_{2} \mathrm{HPO}_{4}, 1$ equiv & 7 (flow) \\
9 & 10 & $\mathrm{~K}_{2} \mathrm{HPO}_{4}, 1$ equiv & 68 \\
10 & 10 & 0.04 & $\mathrm{~K}_{2} \mathrm{HPO}_{4}, 1$ equiv & 78 \\
11 & 10 & 0.08 & $\mathrm{~K}_{2} \mathrm{HPO}_{4}, 0.5$ equiv & 77 \\
12 & 10 & 0.08 & $\mathrm{~K}_{2} \mathrm{HPO}_{4}, 0.25$ equiv & 70 \\
13 & 10 & $\mathrm{~K}_{2} \mathrm{HPO}_{4}, 2$ equiv & $\mathbf{8 9}$ \\
14 & 10 & $\mathrm{KH}_{2} \mathrm{PO}_{4}, 1$ equiv & $75^{\mathrm{c}}$ (flow) \\
15 & 10 & $\mathrm{KH}_{2} \mathrm{PO}_{4}, 1$ equiv & 64 \\
16 & 10 & $\mathrm{KH}_{2} \mathrm{PO}_{4}, 0.5$ equiv & 63 \\
17 & 10 & 0.08 & $\mathrm{KH}_{2} \mathrm{PO}_{4}, 0.25$ equiv & 78 \\
19 & 10 & $\mathbf{0 . 0 8}$ & $\mathrm{KH}_{2} \mathrm{PO}_{4}, 2$ equiv & 54 \\
\hline
\end{tabular}

\footnotetext{
a ${ }^{19} \mathrm{~F}$ NMR yields are reported; ${ }^{\mathrm{b}} 100$ equiv of $\mathrm{H}_{2} \mathrm{O}$ added; ${ }^{c} 5$ minutes of irradiation in batch before flow reaction.
} 
for the synthesis of trifluoromethoxylated compounds. The use of acetonitrile as solvent, rather than the $\mathrm{CH}_{3} \mathrm{CN} / \mathrm{CH}_{2} \mathrm{Cl}_{2}$ mixture previously used [24], further increase the value of this protocol [32] for the synthesis of medicinally relevant molecules.

Based on the reaction mechanism proposed by Ngai and co-authors (Scheme 1C) [24], we hypothesized that the addition of base could potentially improve the reaction outcome. To prove this idea, we performed a series of experiments under batch and flow conditions (Table 2). Organic or soluble bases such as amines and tetrabutylammonium salts (Table 2, entries 1-5) proved unfortunately not successful, neither in batch nor flow, so we extended the investigation to inorganic bases. Among the bases tested, potassium hydrogenphosphates $\mathrm{K}_{2} \mathrm{HPO}_{4}$ and $\mathrm{KH}_{2} \mathrm{PO}_{4}$ led to increased yields, reaching up to $86 \%$ or $89 \%$ in batch (Table 2, entries 7 and 14). Because of the high yields obtained, the use of these bases in flow was investigated. The addition of water [33] allows these bases to be solubilized, preventing clogging; however, this strategy led to a mere $7 \%$ yield (Table 2 , entry 8 ). During batch experiments we noted that after several minutes of irradiation, a homogeneous solution was obtained. Thus, we thought of using this trick for the flow process: irradiation of the reaction mixture in batch for 5 minutes, followed by injection into the microcapillary, provided 2 in $75 \%$ yield (Table 2 , entry 15).

These conditions were also applied to a few other substrates, for the sake of comparison (Figure 1).

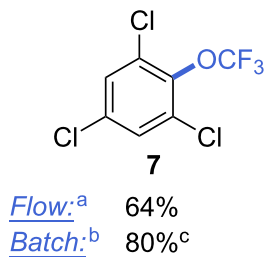<smiles>O=[Se]OC(F)(F)C(F)(F)F</smiles><smiles>FC(F)(F)Oc1ccc(Cl)nc1Cl</smiles>

Figure 1: Effect of $\mathrm{KH}_{2} \mathrm{PO}_{4}$ - other substrates. ${ }^{a}$ Conditions as for entry 15 (Table 2 ), $1 \mathrm{~h}$ residence time; ${ }^{\mathrm{b}}$ conditions as for entry 14 (Table 2 ), 18 h reaction time; ${ }^{c} 0.5$ equiv $\mathrm{KH}_{2} \mathrm{PO}_{4}, \mathrm{CH}_{3} \mathrm{CN} / \mathrm{CH}_{2} \mathrm{Cl}_{2}$ 1:1; d 2 equiv $\mathrm{KH}_{2} \mathrm{PO}_{4} \cdot{ }^{19} \mathrm{~F}$ NMR yields are reported.

Under flow conditions, products $\mathbf{7}, \mathbf{1 0}$, and $\mathbf{3 1}$ were obtained in yields comparable to the base-free method. However, the addition of $\mathrm{KH}_{2} \mathrm{PO}_{4}$ in batch results in considerably improved yields for the same compounds (64-92\%). These experiments demonstrated that the addition of bases indeed represent an interesting modification of the previous protocol, despite being substrate-dependent.

\section{Conclusion}

In summary, we have developed the first continuous-flow trifluoromethoxylation of arenes and heteroarenes. The use of flow photochemistry allows the reaction to occur 16 times faster than in batch, while at the same time achieving similar yields. Thanks to the intrinsic properties of microflow systems, especially for the scale-up of photochemical processes, we anticipate this procedure could be useful in medicinal chemistry applications. In addition, although no beneficial effect could be achieved in flow by the addition of bases, we proved this has a significant effect on the reaction in batch, leading to higher yields. This discovery will be useful for the development of future trifluoromethoxylation methodologies.

\section{Supporting Information}

\section{Supporting Information File 1}

Procedure for continuous-flow and batch

trifluoromethoxylation reactions and ${ }^{19} \mathrm{~F}$ NMR spectra of compounds 2-37.

[https://www.beilstein-journals.org/bjoc/content/ supplementary/1860-5397-16-111-S1.pdf]

\section{Funding}

We acknowledge financial support from AbbVie. T.W. acknowledges support from the China Scholarship Council (CSC). B.C. thanks MINECO for the FPI fellowship BES-2017079784. C.S. acknowledges the European Union for a Marie Curie European post-doctoral fellowship (FlowAct, Grant No. 794072).

\section{ORCID ${ }^{\circledR} \mathrm{iDs}$}

Alexander V. Nyuchev - https://orcid.org/0000-0002-0460-0543 Ting Wan - https://orcid.org/0000-0002-3520-9723 Borja Cendón - https://orcid.org/0000-0003-1783-0839 Carlo Sambiagio - https://orcid.org/0000-0001-8536-103X Job J. C. Struijs - https://orcid.org/0000-0002-6051-2927 Michelle Ho - https://orcid.org/0000-0002-8041-112X Moisés Gulías - https://orcid.org/0000-0001-8093-2454 Ying Wang - https://orcid.org/0000-0001-9516-3483 Timothy Noël - https://orcid.org/0000-0002-3107-6927

\section{References}

1. Szpera, R.; Moseley, D. F. J.; Smith, L. B.; Sterling, A. J.; Gouverneur, V. Angew. Chem., Int. Ed. 2019, 58, 14824-14848. doi:10.1002/anie.201814457

2. Mei, H.; Han, J.; Fustero, S.; Medio-Simon, M.; Sedgwick, D. M.; Santi, C.; Ruzziconi, R.; Soloshonok, V. A. Chem. - Eur. J. 2019, 25 , 11797-11819. doi:10.1002/chem.201901840

3. Purser, S.; Moore, P. R.; Swallow, S.; Gouverneur, V. Chem. Soc. Rev. 2008, 37, 320-330. doi:10.1039/b610213c 
4. Jeschke, P.; Baston, E.; Leroux, F. R. Mini-Rev. Med. Chem. 2007, 7, 1027-1034. doi:10.2174/138955707782110150

5. Landry, M. L.; Crawford, J. J. ACS Med. Chem. Lett. 2020, 11, 72-76. doi:10.1021/acsmedchemlett.9b00489

6. Lee, K. N.; Lei, Z.; Morales-Rivera, C. A.; Liu, P.; Ngai, M.-Y. Org. Biomol. Chem. 2016, 14, 5599-5605. doi:10.1039/c6ob00132g

7. Federsel, D.; Herrmann, A.; Christen, D.; Sander, S.; Willner, H.; Oberhammer, H. J. Mol. Struct. 2001, 567-568, 127-136. doi:10.1016/s0022-2860(01)00541-5

8. Lee, K. N.; Lee, J. W.; Ngai, M. Y. Synlett 2016, 27, 313-319. doi:10.1055/s-0035-1560516

9. Lee, J. W.; Lee, K. N.; Ngai, M.-Y. Angew. Chem., Int. Ed. 2019, 58, 11171-11181. doi:10.1002/anie.201902243

10. Tlili, A.; Toulgoat, F.; Billard, T. Angew. Chem., Int. Ed. 2016, 55, 11726-11735. doi:10.1002/anie.201603697

11. Ghiazza, C.; Billard, T.; Tlili, A. Chem. - Eur. J. 2019, 25, 6482-6495 doi:10.1002/chem.201806234

12. Umemoto, T.; Adachi, K.; Ishihara, S. J. Org. Chem. 2007, 72, 6905-6917. doi:10.1021/jo070896r

13. Stanek, K.; Koller, R.; Togni, A. J. Org. Chem. 2008, 73, 7678-7685. doi:10.1021/j08014825

14. Liu, J.-B.; Chen, C.; Chu, L.; Chen, Z.-H.; Xu, X.-H.; Qing, F.-L. Angew. Chem., Int. Ed. 2015, 54, 11839-11842. doi:10.1002/anie.201506329

15. Huang, C.; Liang, T.; Harada, S.; Lee, E.; Ritter, T. J. Am. Chem. Soc. 2011, 133, 13308-13310. doi:10.1021/ja204861a

16. Yang, S.; Chen, M.; Tang, P. Angew. Chem., Int. Ed. 2019, 58, 7840-7844. doi:10.1002/anie.201901447

17. Yang, Y.-M.; Yao, J.-F.; Yan, W.; Luo, Z.; Tang, Z.-Y. Org. Lett. 2019, 21, 8003-8007. doi:10.1021/acs.orglett.9b03000

18. Govaerts, S.; Nyuchev, A.; Noel, T. J. Flow Chem. 2020, 10, 13-71. doi:10.1007/s41981-020-00077-7

19. Sambiagio, C.; Schönbauer, D.; Blieck, R.; Dao-Huy, T.; Pototschnig, G.; Schaaf, P.; Wiesinger, T.; Zia, M. F.; Wencel-Delord, J.; Besset, T.; Maes, B. U. W.; Schnürch, M. Chem. Soc. Rev. 2018, 47, 6603-6743. doi:10.1039/c8cs00201k

20. Romero, N. A.; Nicewicz, D. A. Chem. Rev. 2016, 116, 10075-10166. doi:10.1021/acs.chemrev.6b00057

21. Prier, C. K.; Rankic, D. A.; MacMillan, D. W. C. Chem. Rev. 2013, 113, 5322-5363. doi:10.1021/cr300503r

22. Narayanam, J. M. R.; Stephenson, C. R. J. Chem. Soc. Rev. 2011, 40, 102-113. doi:10.1039/b913880n

23. Zheng, W.; Morales-Rivera, C. A.; Lee, J. W.; Liu, P.; Ngai, M.-Y. Angew. Chem., Int. Ed. 2018, 57, 9645-9649. doi:10.1002/anie.201800598

24. Zheng, W.; Lee, J. W.; Morales-Rivera, C. A.; Liu, P.; Ngai, M.-Y. Angew. Chem., Int. Ed. 2018, 57, 13795-13799. doi:10.1002/anie.201808495

25. Jelier, B. J.; Tripet, P. F.; Pietrasiak, E.; Franzoni, I.; Jeschke, G.; Togni, A. Angew. Chem., Int. Ed. 2018, 57, 13784-13789. doi:10.1002/anie.201806296

26. Santoro, S.; Ferlin, F.; Ackermann, L.; Vaccaro, L. Chem. Soc. Rev. 2019, 48, 2767-2782. doi:10.1039/c8cs00211h

27. Sambiagio, C.; Noël, T. Trends Chem. 2020, 2, 92-106. doi:10.1016/j.trechm.2019.09.003

28. Cambié, D.; Bottecchia, C.; Straathof, N. J. W.; Hessel, V.; Noël, T. Chem. Rev. 2016, 116, 10276-10341.

doi:10.1021/acs.chemrev.5b00707
29. Bottecchia, C.; Rubens, M.; Gunnoo, S. B.; Hessel, V.; Madder, A.; Noël, T. Angew. Chem., Int. Ed. 2017, 56, 12702-12707. doi:10.1002/anie.201706700

30. Straathof, N. J. W.; Cramer, S. E.; Hessel, V.; Noël, T. Angew. Chem., Int. Ed. 2016, 55, 15549-15553. doi:10.1002/anie.201608297

31. Wei, X.-J.; Abdiaj, I.; Sambiagio, C.; Li, C.; Zysman-Colman, E.; Alcázar, J.; Noël, T. Angew. Chem., Int. Ed. 2019, 58, 13030-13034. doi:10.1002/anie.201906462

32. Henderson, R. K.; Jiménez-González, C.; Constable, D. J. C.; Alston, S. R.; Inglis, G. G. A.; Fisher, G.; Sherwood, J.; Binks, S. P.; Curzons, A. D. Green Chem. 2011, 13, 854-862. doi:10.1039/c0gc00918k

33. The use of water was reported not to interfere with the reaction [24].

\section{License and Terms}

This is an Open Access article under the terms of the Creative Commons Attribution License

(http://creativecommons.org/licenses/by/4.0). Please note that the reuse, redistribution and reproduction in particular requires that the authors and source are credited.

The license is subject to the Beilstein Journal of Organic Chemistry terms and conditions: (https://www.beilstein-journals.org/bjoc)

The definitive version of this article is the electronic one which can be found at: doi:10.3762/bjoc.16.111 